\title{
Study of the Major League Baseball Collective Bargaining and Baseball
}

\author{
Yen-Chieh Wen ${ }^{1 *}$, Ming-Sung Tsai ${ }^{2}$
}

${ }^{1}$ Associate Professor, Physical Education Office, National Taiwan University of Arts, New Taipei City, Taiwan (R.O.C)

${ }^{2}$ Assistant professor, Department of Sports Management, Minghsin University of Science and Technology, Taiwan (R.O.C)

\author{
DOI: $\underline{10.36348 / \text { jaspe.2020.v03i06.001 }}$ \\ | Received: 15.05.2020 | Accepted: 23.05.2020 | Published: 26.06.2020
}

*Corresponding author: Yen-Chieh Wen

\section{Abstract}

This research analyzes the main reasons for major league baseball strikes by collecting relevant literature and applying negotiation theory. The study found that in addition to tensions and hostility between employers and employees over a history of unharmonious negotiations, there was also a delay in reaching a consensus on the "salary cap" issue in the main reasons leading to the strike. During the entire negotiation process, the player union and the team owner most of the time adopt a distributed negotiation model and apply competitive strategies and tactics to try to make the other party concede, resulting in a serious negotiation deadlock. Therefore, this study suggests that in the future professional sports leagues should expand the resources available to both employers and employees in the common interest when facing controversial issues such as salary, so as to avoid the occurrence of labor disputes.

Keywords: Major League Baseball, strike.

Copyright @ 2020: This is an open-access article distributed under the terms of the Creative Commons Attribution license which permits unrestricted use, distribution, and reproduction in any medium for non-commercial use (NonCommercial, or CC-BY-NC) provided the original author and source are credited.

\section{INTRODUCTION}

Baseball captures the passion and affection of America and remains the nation's favorite pastime. As orator Chauncey Depew exclaimed at a banquet honoring America's greatest baseball players' back from a six-month tour around the world, "I believe that all men who have ever lived and achieved success in this world had lived in vain if they knew not baseball".

Baseball is revered by players, who have been "nurtured on the same set of dreams, myths, and realities about what it meant to be a major leaguer. Players talk about 'the game' in mystical, reverential terms years after they are away from the sport and the business of baseball" [1]. Indeed, baseball players feel the hold "the game" has on their lives. Baseball players love playing the game, and most feel lucky to be the few elites to do something that millions of other young men would give up almost anything to do.

Baseball is a game of numbers. "To fans, numbers are batting averages, earned run averages, and home run totals. To players, numbers also meant limited spots on rosters, short careers, and very few coaching and front office jobs. To owners, they count on the players and control, manipulate players" [1]. Collective bargaining in baseball in America has followed the model of other labor movements, focusing on concrete workplace issues, the so-called "bread-and-butter" issues, rather than ideological or political issues. The economic, or the money issues, such as wage, compensation for the players are at the heart of the collective bargaining in baseball. Due to the special nature of athletes' work, special labor security must be worked out to maintain competitiveness and employers' rights [4].

\section{The evolution of labor relations in baseball over the decades - the pre-miller eras}

Labor relations in American baseball had been going on for decades. It took "nearly a hundred years for basic marketplace freedom to come to baseball players" [3]. "To many fans, the ballplayer leads a life of envious ease. He plays a boy's game for two hours a day and then is adored by an admiring public. To many owners, the ballplayer is an expensive toy to be wound up and sold and traded at whim [3]". However, in real life, the baseball player is "a worker in an industry and a part of the product. He is also a businessman with a rare but will-o'-the-wisp skill. But until the emergence of a strong Major League Baseball Players Association in the late 1960's, the player had very little leverage against the ownership of major league baseball".

The players' powerlessness is manifested in the Manifesto of Brotherhood of Professional Baseball Players, November 6, 1889. It states that "by a 
combination among themselves, stronger than the strongest trust, the owners were able to enforce the most arbitrary measures, and the player had either to submit or get out of the profession in which he had spent years attaining proficiency" [3].

\section{No Negotiation on Salary}

Marvin Miller, the first full-time executive director of the Major League Baseball Players Association, said that although the major league baseball players ranked top in their profession, they were at the whim of their powerful owners. They were paid "pitifully" before the collective bargaining eras [5]. Despite the rampant inflation over a twenty- year period before 1965, the major league players' minimum salary went from $\$ 5,000$ to $\$ 6,000$ a year. Their average salary was $\$ 19,000$. After World War II, “only superstars like Ted Williams, Stan Musial, Joe DiMaggio, Willie Mays, and Mickey Mantle had reached unofficial maximum of $\$ 100,000$ " [5]. When Pirates slugger Ralph Kiner, "the man with the second-highest home run to at-bats percentage in baseball history" asked for a raise, he was sneered with such a reply from the team's general manager Branch Rickey: "We finished last with you; we could have finished last without you! [5]". Despite Ralph Kiner's huge market value as a professional baseball player, despite the fact that without Ralph Kiner, Branch Richey would have sold so many fewer tickets, Branch Richey did not bother to acknowledge the value of a professional baseball player. Branch Richey's obnoxious attitude was typical of that of owners toward their players at the time.

\section{No Change of Status Quo (Reserve Clause)}

In 1963, Bob Friend defended, "The reserve clause is an absolute must for the survival of baseball, and during the thirteen years I have been in the National League I know of no player who has been exploited" [1]. In Bob Friend's opinion, players would be better off with their owners than with union. He claimed that a union "would not fit the situation in baseball [because] players and management work closely together. It would destroy baseball if fans were exposed to the spectacle of someone like Stan Musial picketing a ball park" [1].

\section{No Power to Change Working Conditions}

In 1990, the thirty-two-day lockout occurred during spring training $[2,8]$. On the one hand, the owners sought "radical restructuring of the collective bargaining agreement," seeking revenue sharing, a salary cap limiting the total salary a team could pay to its players. On the other hand, the players demanded for "the restoration of the two-year period of prior service" instead of three-year period to be eligible for salary arbitration. Moreover, players demanded a doubling of minimum salaries and the continuation of the pension and health benefit plan. The then-commissioner Fay Vincent played an important role in ending the strike.
Seventy-eight games postponed by the lockout were rescheduled [8].

\section{The 1994-1995 Strike}

The strike of 1994-1995 was the worst battle of all. It caused trepidation in the hearts of baseball fans. It is an experience that neither players nor owners wish to repeat [2]. First, it began with owners' decision in December 1992 to re-start the "negotiation on salary and the free agency system." Second, the owners pressured Commissioner Vincent to resign and left the office vacant. The focus of the owners' intention was to solve the disparity between big-market teams and small-market teams. However, they linked this problem with the salary cap, which made players feel that they were asked to solve the owners' disparity problem. Moreover, salary cap would require small-market teams to pay salaries up to a certain minimum. Small-market teams wanted subsidies to meet the minimum and to prevent big-market teams making too many profits. The idea of such revenue sharing caused divisiveness among the owners [7]. In the 1994 Major League Baseball strike, the length of the strike allowed the National Labor Relations Committee to have a lot of time to investigate and then make a ruling. The ruling at the time was crucial and allowed the 1995 season to start [6].

The players began the strike on August 12, 1994. On September 14, 1994, "the owners declared the cancellation of the World Series for the first time since 1904" [7]. The strike ended on March 31, 1995, when Judge Sotomayor granted the NLRB's request for a preliminary injunction against the owners." The union called off the strike. "Nothing was settled by the strike, because the old contract provisions continued to apply, which has to make the strike one of the most eventful, but unproductive, ever".

\section{CONCLUSION}

This research hopes that owners and players of the collective bargaining in baseball would work on a level of cooperation and understanding in the future. Working on problems and develop a mutual trust between the players and owners is crucial in improving the often troubled bargaining relations. Moreover, improvements in team and league management and the way they negotiate may ameliorate many of the labor relation problems common in the professional baseball and help achieve labor peace in baseball.

\section{REFERENCES}

1. Korr, C. P. (2000). From Judge Cannon to Marvin Miller: From Players' Group to Players' Union. In Staudohar, P. D. [2000 Ed]. Diamond Mines: Baseball and Labor. Syracuse, NY: Syracuse University Press.

2. Koziara, K. S. (2000). Labor Relations in Baseball. In Staudohar, P. D. [2000 Ed]. Diamond 
Mines: Baseball and Labor. Syracuse, NY: Syracuse University Press.

3. Lowenfish, L., \& Creamer, R.W. (1991). The Imperfect Diamond: A history of Baseball's Labor Wars. Canada: Bison Books.

4. Mpellou, M. (2015). The Necessity of Regulation or/and Re-regulation of Sports Labor Relationships, Especially Those of Amateur Athletes, International Sports Law Review, 11(1/2), $172-190$.

5. Miller, M. (2004). A Whole Different Ball Game: The Inside Story of the Baseball Revolution. Chicago, Illinois: Ivan R. Dee.
6. Munson, L. (2011). "NBA Litigation Reverses NFL Roles.” Retrieved from http://espn.go.com/espn/commentary/story/_/page /munson-110802/nba-owners-first-strike-lockoutlitigation-aimed-favorable-court-location

7. Staudohar, P. D. (2000). The Baseball Strike of 1994-95. In Staudohar, P. D. [2000 Ed]. Diamond Mines: Baseball and Labor. Syracuse, NY: Syracuse University Press.

8. Staudohar, P. D. (2000). Baseball's Changing Salary Structure. In Staudohar, P. D. [2000 Ed]. Diamond Mines: Baseball and Labor. Syracuse, NY: Syracuse University Press. 